\title{
LITERASI KEUANGAN UMKM BERBASIS DESA
}

\author{
V.Wiratna Sujarweni \\ Email: nana_wiratna@yahoo.com \\ Universitas Respati Yogyakarta \\ Prodi Akuntansi Fakultas Ilmu Sosial Dan Ekonomi
}

\begin{abstract}
Abstrak
Era globalisasi menyebabkan banyaknya arus modal asing yang masuk ke negara kita, pemberlakuan Masyarakat Ekonomi Asean (MEA) agenda dimana di kawasan Asia Tenggara akan membentuk suatu pasar tersendiri yang akan memungkinkan adanya perdagangan bebas barang, jasa, dan investasi sehingga kompetisi akan semakin ketat. Bisnis waralaba bermodal asing banyak dibuka di kotakota sejumlah wilayah Indonesia. Untungnya desa-desa belum masuk bisnis waralaba tersebut, maka dari itu jangan sampai bisnis waralaba bermodal asing itu masuk di tingkat pedesaan. Apabila sampai terjadi maka kemandirian ekonomi nasional tidak akan terwujud. Salah satu upaya yang harus kita lakukan adalah melalui pemberdayaan Usaha Mikro Kecil Menengah (UMKM) dan desa. Pemerintahan desa merupakan pemerintahan terkecil dari negara, akan lebih teliti jika pendataan, literasi keuangan, pengawasan UMKM ada di tingkat desa, apalagi ada program dana desa dengan jumlah milyaran rupiah mengalir langsung ke desa, diharapkan UMKM desa dapat mengalami kemajuan.

Berdasarkan Survei Nasional Literasi Keuangan Indonesia yang dilakukan oleh Otoritas Jasa Keuangan (OJK) pada tahun 2013, diketahui tingkat literasi masyarakat Indonesia masih rendah. Pelaku UMKM di tingkat desa dapat diberikan literasi keuangan. Pemerintah, OJK bekerja sama dengan desa membuat program upaya kemajuan UMKM. OJK dapat berkoordinasi dengan kepala desa untuk melakukan pendataan UMKM masing-masing desa, UMKM digolongkan yang mau berkembang dan tidak. Selanjutnya dari pendataan tersebut dilakukan edukasi literasi keuangan. Bagi UMKM golongan yang mau berkembang ini diprioritaskan untuk dilakukan edukasi serta pendampingan. Adapun dana untuk penyelenggaraannya dapat dikoordinasikan dengan kepala desa setempat dengan menggunakan sedikit dana desa. Penyelenggaraan cukup diadakan di balai desa dengan materi mencakup perencanaan keuangan, pelaporan keuangan, manfaat dan proses pengajuan kredit, serta ases UMKM yang dapat menembus bursa efek Indonesia.

Materi yang akan disajikan ini dibuat sederhan namun dapat dipahami oleh pemikiran masyarakat desa, mudah dipraktekkan dalam usahanya. Penulis juga telah membuat bahan materi pelaporan keuangan (ada di lampiran) yang mudah diterapkan dan sudah pernah disampaikan dalam Pelatihan kelompok Usaha Bersama yang diselenggaran oleh BKKBN dan sudah digunakan dalam usaha mereka. Materi ini dikembangkan tidak jauh dari prinsip pembuatan laporan akuntansi desa, materi berupa contoh kasus secara langsung baik untuk usaha yang bergerak dalam bidang jasa, dagang, dan industri penghasil barang. Setelah dilakukan literasi, UMKM didampingi, diawasi, dan akan dijadikan percontohan. Harapan ke depan dengan adanya dana desa milyaran rupiah ini masing-masing desa mempunyai Badan Usaha Desa seperti swalayan sebagai tempat pendistribusian hasil dari UMKM desa setempat ataupun desa-desa lain. Sehingga kebutuhan masyarakat akan dapat dipenuhi oleh hasil UMKMUMKM desa. Bahkan jika UMKM masing-masing desa akan berkembang maka hasil-hasilnya akan dapat dieksport sampai manca negara.
\end{abstract}

Kata Kunci : Literasi, UMKM, Desa

\section{Latar Belakang}

Seiring perkembangan zaman dan globalisasi menyebabkan banyaknya arus modal asing yang masuk ke negara kita, menjadikan kegelisahan yang mendalam yang dirasakan dimana kekuatan kapitalisme global melalui kehadiran perusahaan-perusahaan asing yang masuk hingga kedasar perekonomian Indonesia.

Dengan kekuatan modal asing tersebut telah menguasai perusahaan di beberapa sektor seperti industri pertambangan, telekomunikasi, perbankan, otomotif, konsumer, elektronik, farmasi, ritel, dan yang lainnya, dengan kekuatan modal, kekuatan teknologi, manajemen, dan tenaga kerja berkelas dunia. Ada juga online shop yang terus berkembang pesat di negara ini, 
demikian juga perusahaan yang mendominasi onlineshop tersebut adalah kekuatan modal asing juga.

Bisnis waralaba makanan asing merajalela di pasar penjuru tanah air, bisnis ini terus melakukan ekspansi. Bisnis waralaba yang sedang berekspansi tersebut jangan sampai membuat terlena, jika kita terlena maka tidak khayal akan menyingkirkan bisnis makanan lokal yang menjadi ciri khas dan sumber bagi kekayaan Indonesia. Jangan sampai makanan khas Indonesia seperti Pecel, Empek-empek, gudeg, dan lain sebagainya semakin lama tidak dikonsumsi, bahkan tidak dikenal oleh generasi anak cucu kita, namun yang dikonsumsi dan dikenal adalah makanan asing seperti Pizza, Hamburger, Spageti, dan sejenisnya.

Saat ini bisnis waralaba bermodal asing banyak dibuka di kota-kota besar di sejumlah ibu kota, propinsi, kabupaten di Indonesia. Untungnya desa-desa belum masuk bisnis waralaba tersebut, maka dari itu jangan sampai bisnis waralaba bermodal asing itu masuk di tingkat pedesaan. Apabila sampai terjadi maka kemandirian ekonomi nasional tidak akan terwujud.

Apalagi pada tahun 2015 telah diberlakukan adanya Masyarakat Ekonomi Asean (MEA), MEA merupakan bentuk realisasi dari tujuan akhir integrasi ekonomi di kawasan Asia Tenggara. MEA sendiri diartikan sebagai sebuah agenda dimana di kawasan Asia Tenggara akan membentuk suatu pasar tersendiri yang akan memungkinkan adanya perdagangan bebas barang, jasa, dan investasi. Satu negara memungkinkan menjual barang dan jasa dengan mudah ke negara-negara lain di seluruh Asia Tenggara sehingga kompetisi akan semakin ketat. Indonesia dapat digempur oleh produk-produk barang dari Cina dengan kualitas baik dan harga yang lebih murah. MEA ini sebenarnya akan memberi kesempatan bagi masyarakat Indonesia untuk menarik keuntungan dari pasar yang lebih luas di Asean. Namun ini menjadi tantangan karena Indonesia bisa tergerus jika produknya kalah saing dengan Negara lain (G.T Sutoso dan Widyaiswara, $2015)^{[2]}$
Sebelum modal asing, barang dan jasa negara lain menguasai negara kita, untuk menanggulinya banyak upaya yang harus kita lakukan untuk mewujudkan kemandirian ekonomi nasional. Salah satu upaya menciptakan kemandirian ekonomi Indonesia adalah melalui pemberdayaan Usaha Mikro Kecil Menengah (UMKM) dan desa. Jangan sampai usaha UMKM lokal ini juga akan diambil alih oleh pemodal asing, jika ini sampai terjadi maka rakyat tidak akan menjadi tuan rumah di negara sendiri dan sudah pasti tidak akan terwujud kemandirian nasional.

UMKM betul-betul menjadi harapan terakhir untuk mewujudkan kemandirian ekonomi nasional, karena ukuran UMKM yang kecil ini, kekuatan modal asing mungkin enggan mengambil alih karena potensinya yang kecil pula. Meskipun kecil namun jika jumlah UMKM banyak dan semuanya berkembang maka kekhawatiran ini tidak akan terwujud.

UMKM memiliki peran yang sangat besar dalam perekonomian Indonesia. Menurut data BPS 2014, jumlah UMKM di Indonesia sebanyak 57,89 juta unit, atau 99,99 persen dari total jumlah pelaku usaha nasional. UMKM memberikan kontribusi terhadap kesempatan kerja sebesar 96,99 persen, dan terhadap pembentukan PDB sebesar 60,34 persen. UMKM juga berkontribusi dalam penambahan devisa negara dalam bentuk penerimaan ekspor sebesar 27.700 milyar dan menciptakan peranan $4,86 \%$ terhadap total ekspor. Kontribusi UMKM terhadap devisa negara tersebut jauh lebih kecil daripada kontribusi usaha besar, sehingga UMKM lebih diberdayakan.

UMKM kita selama ini banyak bergerak di sektor informal di pedesaan dan cenderung belum mendapatkan informasi yang baik. UMKM sendiri selama ini masih gagap menghadapi persaingan domestik dengan usaha menengah dan besar, namun sekarang tiba-tiba harus menghadapi sesama UMKM dari semua negara ASEAN dan juga modal asing yang di luar negara ASEAN.

Desa dipandang sebagai kekuatan terakhir untuk mewujudkan kemandirian ekonomi nasional. Menurut UU No 6 tahun 
2014 pasal 1 ayat 1 desa adalah kesatuan masyarakat hukum yang memiliki batas wilayah yang berwenang untuk mengatur dan mengurus urusan pemerintahan, kepentingan masyarakat setempat berdasarkan prakarsa masyarakat, hak asal usul, dan/atau hak tradisional yang diakui dan dihormati dalam sistem pemerintahan Negara Kesatuan Republik Indonesia. Pemerintahan Desa merupakan lembaga perpanjangan pemerintah pusat memiliki peran yang strategis untuk mengatur masyarakat yang ada di pedesaan demi mewujudkan pembangunan pemerintah. Berdasarkan Undang-Undang desa 6 tahun 2014 pasal 72 ayat 3 menyebutkan Alokasi dana Desa minimal akan digelontorkan secara langsung ke desa sebanyak 10\% dari dana perimbangan yang akan diterima oleh Kabupaten/Kota. Jadi setiap tahun desa akan menerima dana milyaran rupiah untuk kemajuan desa. ${ }^{[3]}$

Untuk mewujudkan kemajuan UMKM pengelolaan keuangan yang akuntabel, dan bernilai tambah merupakan kunci suksesnya. Oleh karena itu, diperlukan upaya-upaya strategis guna meningkatkan kinerja dan keberlangsungan UMKM. Salah satu cara yang dapat dilakukan adalah dengan memperkaya pengetahuan pelaku UMKM terhadap pengetahuan keuangan sehingga pengelolaan dan akuntabilitasnya bisa dipertanggungjawabkan dengan lebih baik sebagaimana layaknya perusahaan besar. Literatur telah banyak yang mengkonfirmasi bahwa kemampuan perusahaan dalam mengenali dan mengakses sumber daya keuangan akan berdampak pada tingkat pertumbuhan perusahaan (Binks dan Ennew, 1996; Bygrave dan Zacharakis, 2008; Grande, Madsen, dan Borch, 2011; Adomoko et al., 2016) dalam (Dwitya, 2016). Maka dalam hal ini dibutuhkan literasi keuangan UMKM yang akan mendorong kemajuannya $^{[1]}$

Pemerintahan desa merupakan bagian terkecil dari pemerintahan negara, akan lebih teliti jika pendataan adanya UMKM di tingkat desa terlebih dahulu, kemudian baru kita pilih mana saja UMKM yang tergolong mau berkembang dan UMKM yang tidak tergolong mau berkembang. Baru dilakukan edukasi literasi keuangan dan pendampingan usaha.

Berdasarkan hasil penelitian di sebuah desa di wilayah Klaten dengan hasil utama padi. Saran dari hasil penelitian yang dibuat peserta ini, bahwa untuk lebih baiknya desa harus melakukan pendataan jumlah warganya, kemudian berdasarkan jumlah warga dibuat perkiraan kebutuhan beras untuk setiap bulannya. Maka hasil dari pertanian di wilayah desa tersebut akan lebih baik dipenuhi oleh UMKM-UMKM yang menghasilkan beras di desa tersebut, baru sisanya kita dapat distribusikan ke luar desa. Dalam hal ini ada warga yang mempunyai usaha penggilingan padi, sedangkan desa dapat mendirikan toko untuk menampung hasil beras dari warga sekitar. Namun selama ini para petani hanya menjual hasil padinya kepada tengkulaktengkulak besar dengan harga yang rendah.

Apalagi dana desa yang saat ini bernilai milyaran rupiah dapat digunakan untuk membangun Badan Usaha Desa, salah satunya pendirian swalayan milik desa yang akan menampung produk-produk dari UMKM di desa setempat maupun di desa lain tempat. Seperti hasil penelitian di wilayah Kulon Progo Yogyakarta, bahwa di wilayah tersebut kini telah berdiri swalayanswalayan milik rakyat kabupaten tersebut. Awalnya dahulu adalah bisnis waralaba Alfamart, kemudian oleh Bupati Kulon Progo, Alfamart yang telah habis ijin dan Alfamart yang tidak memenuhi syarat kemudian diambil alih oleh kabupaten Kulonprogo dan dialihkan menjadi swalayan TOMIRA (Toko Milik Masyarakat) yang dikelola oleh koperasikoperasi desa. Adapun barang-barang yang dijual adalah barang-barang milik UMKM warga Kulon Progo.

UMKM dan desa menjadi pilar kemandirian ekonomi nasional, kita perlu membuat agenda besar yang perlu dirintis dan dikembangkan dengan cara menciptakan wirausahawan UMKM di tingkat desa dalam jumlah besar. Maka dari itu UMKM di tingkat desa perlu di data dan dilakukan edukasi literasi keuangan.

Mekanisme dalam pemberian literasi keuangan untuk UMKM ini, berawal dari tingkat desa. Dari tingkat desa akan 
dilakukan pendataan UMKM apa saja yang ada di daerah tersebut. Kemudian setelah dilakukan pendataan, UMKM dibagi kedalam UMKM yang mau berkembang dan tidak mau berkembang. Apabila di daerah tersebut tidak terdapat UMKM namun mempunyai potensi besar pada sumber daya, maka perlu didorong untuk membuka UMKM sendiri. Misalnya Berdasarkan survey peserta di desa Gading Gunung Kidul Yogyakarta merupakan penghasil tanaman kayu putih, bahkan setiap warga desa disana kebanyakan mempunyai tanaman kayu putih sendiri di pekarangan rumahnya. Namun selama ini hasil dari tanaman kayu putih ini hanya dijual di perusahaan besar dengan harga yang cukup murah. Dengan memberikan motivasi dan pelatihan cara mengolah sendiri minyak kayu putih serta mengelola usaha sendiri, maka mereka dapat mendirikan UMKM sendiri. Bahkan jika desa mempunyai tempat untuk distribusi setiap UMKM tersebut tidak khayal kalau warga akan menjadi makmur.

UMKM yang sudah di data dan sudah digolongkan tersebut akan diberikan literasi keuangan. Berkaitan dengan dana desa yang dikucurkan milyaran setiap tahunnya, maka OJK dapat bekerja sama dengan kepala desa di seluruh wilayah untuk menyisihkan sedikit dana untuk memajukan UMKM di desa masing-masing. Tentu saja dana yang akan diberikan kepala desa tersebut mempunyai syarat-syarat dan kebijakankebijakan khusus yang patut untuk dipatuhi. Bagi UMKM yang dipandang mau berkembang ini, desa lebih memprioritaskan untuk diberikan edukasi literasi keuangan, kemudian pendampingan khusus, sehingga UMKM itu bisa berhasil dan dapat menjadi percontohan buat UMKM-UMKM yang tidak mau berkembang.

Literasi keuangan yang akan diberikan kepada UMKM tersebut dirancang dengan mencakup 4 materi, yaitu perencanaan keuangan, pembuatan laporan keuangan, manfaat dan proses pengajuan kredit, serta ases UMKM yang dapat menembus bursa efek Indonesia. Adapun 4 materi yang akan disajikan ini dibuat sesederhana mungkin namun dapat dipahami oleh pemikiran masyarakat desa. Materi ini jangan sampai memberatkan pelaku UMKM. Menurut pengalaman penulis yang sudah pernah mendampimpingi pelatihan Kelompok Usaha besama pembuatan laporan keuangan yang diberikan dengan menggunakan basic doble entry bookeping, akan menyulitkan mereka, yang pada akhirnya mereka malah setelah pelatihan tidak melakukan pembukuan karena rumit dan ribet. Maka pada kesempatan kali ini penulis memberikan bahan materi pelaporan keuangan (di lampiran) yang mudah dipraktekan dan diterapkan, pembukuan ini dikembangkan tidak jauh dari prinsip pembuatan laporan akuntansi desa, materi berupa contoh kasus secara langsung. Materi ini sudah disampaikan di pelatihan kelompok Usaha Bersama yang diselenggaran oleh BKKBN dan sudah digunakan dalam usaha mereka. Sedangkan tempat yang digunakan sebagai edukasi literasi keuangan dapat dilakukan di balai desa atau pendopo desa.

Berdasarkan latar belakang yang peserta tuliskan di atas peserta sangat tertarik untuk mengajukan ide mengenai "Literasi Keuangan UMKM Berbasis Desa"

\section{Diskripsi Model Bisnis}

Desa sebagai kelompok terkecil dalam tatanan pemerintah ini dapat digunakan sebagai ajang edukasi keuangan untuk memberikan literasi keuangan bagi para pemilik UMKM di wilayah desa. OJK bekerja sama dengan desa-desa di seluruh wilayah Indonesia untuk membuat program kemajuan UMKM. Dengan adanya dana desa milyaran rupiah setiap tahunnya, OJK dapat menghubungi dan berkoordinasi dengan kepala desa untuk melakukan pendataan UMKM masing-masing desa, kemudian menggolongkannya termasuk UMKM yang mau berkembang ataukah tidak. Selanjutnya dari pendataan tersebut dilakukan edukasi literasi keuangan kepada UMKM masing-masing desa berdasarkan pendataan dan penggolongan UMKM yang sudah dilakukan. Bagi UMKM golongan yang mau berkembang ini diprioritaskan untuk dilakukan edukasi serta pendampingan. Adapun dana untuk penyelenggaraan pendataan, edukasi, pendampingan, sampai pemantauan UMKM 
desa dapat dikoordinasikan dengan kepala desa setempat dengan menggunakan sedikit dana desa. Penyelenggaraan cukup diadakan di balai desa dengan materi mencakup perencanaan keuangan, pelaporan keuangan, manfaat dan proses pengajuan kredit, serta ases UMKM yang dapat menembus bursa efek Indonesia.

Adapun 4 materi yang akan disajikan ini dibuat sesederhana mungkin namun dapat dipahami oleh pemikiran masyarakat desa. Materi ini jangan sampai memberatkan pelaku UMKM. Menurut pengalaman peserta yang sudah pernah mendampimpingi pelatihan Kelompok Usaha Besama mengenai pembuatan laporan keuangan yang diberikan dengan menggunakan basic doble entry bookeping, akan menyulitkan mereka, yang pada akhirnya mereka malah setelah pelatihan tidak melakukan pembukuan karena rumit dan ribet. Maka pada kesempatan kali ini penulis memberikan bahan materi perencanaan dan pelaporan keuangan dengan mudah diterapkan, pembukuan ini dikembangkan tidak jauh dari prinsip pembuatan laporan akuntansi desa, materi berupa contoh kasus secara langsung. Materi ini sudah disampaikan di pelatihan kelompok Usaha bersama yang diselenggaran oleh BKKBN dan sudah digunakan dalam usaha mereka. Sedangkan tempat yang digunakan sebagai edukasi literasi keuangan dapat dilakukan di balai desa ataupun pendopo desa.

Dari adanya penyelenggaraan edukasi literasi keuangan ini perlu dilakukan pengawasan dan target keberhasilan UMKM. Adapun target dari edukasi ini adalah UMKM yang dapat menjadi percontohan sehingga bagi UMKM yang tergolong tidak mau berkembang ini akan terpacu.

Kemudian untuk kedepannya dana desa milyaran rupiah ini dapat benar-benar digunakan oleh desa untuk memajukan desa. Harapannya setiap desa akan mempunyai Badan Usaha Sendiri, salah satunya setiap desa mempunyai swalayan sendiri yang barang dagangannya diambil dari UMKM di desa setempat dan juga bisa dari desa-desa lain. Maka kemandirian ekonomi akan tercapai, harga pokok produksi dapat ditekan, biaya angkut barang juga akan lebih rendah dibanding kita akan mengimport barang dari negara lain.

\section{Dampak Inovasi}

Dalam kegiatan ini mempunyai manfaat dimana untuk mendata UMKM sebaiknya dilakukan di tingkat desa, karena pendataan ini akan lebih rinci dan detail. Akan juga diketahui UMKM yang tergolong mau berkembang dan tidak. Dari hasil pendataan ini, kemudian dilakukan edukasi terutama para UMKM yang mau berkembang. Tentu dampak dari edukasi literasi keuangan bagi pelaku UMKM ini adalah mereka dapat memahami bagaimana cara melakukan perencanaan keuangan usaha, membuat laporan keuangan, memahami manfaat kredit serta proses pengajuan kredit, memahami mekanisme penambahan modal melalui bursa efek Indonesia.

Dalam perencanaan keuangan diharapkan pelaku UMKM dapat membuat rencana keuangan dengan anggaran, dapat melakukan perhitungan harga pokok produk barang maupun jasa usahanya, UMKM dapat disiplin untuk mengelola Keuangan seperti yang sudah direncanakan. Paham bahwa usaha harus dipisahkan antara uang rumah tangga untuk kebutuhan hidup sehari hari dengan keuangan untuk usaha, walaupun usaha tersebut dijalankan di rumah. Dapat melakukan rencana masa depan usahanya, termasuk merencanaan keuangan untuk pengembangan usaha kedepan. Bakhan mampu merencanakan keuangan yang berasal dari kredit dari lembaga keuangan/perbankan.

Literasi kedua adalah edukasi pelaporan keuangan, harapannya pembuatan laporan keuangan yang dilakukan berdasarkan transaksi sehari-hari tidak mempersulit pelaku UMKM, sehingga pelaku usaha dapat membuat laporan keuangan berupa buku kas, buku bank, buku aktiva, buku piutang, buku hutang, buku penjualan, buku pembelian, bahkan bisa menghasilkan neraca, rugi laba dari transaksi-transaksi usahanya. Pelaku usaha paham juga pelaporan keuangan usaha berdasarkan usaha jasa, perdagangan, dan industri. Dalam edukasi ini sebaiknya dilakukan praktek pembukuan berdasarkan 3 usaha tersebut, sehingga pelaku benar-benar 
memahami karena materi pengajaran langsung contoh kasus beserta penyelesaiannya.

Literasi ketiga adalah berupa manfaat dan proses kredit bank. Pelaku usaha diharapkan dapat memahami apa saja manfaat penambahan modal, bagaimana cara mendapatkan modal usaha dengan bunga rendah, merencanakan kredit, cara menghitung bunga kredit, dan apa saja jaminannya. Setelah mengetahui literasi ketiga ini, setelah menerima kredit dari Lembaga Keuangan/Perbankan, pelaku UMKM harus menggunakan uangnya untuk mengembangkan usaha, tidak menyalahgunakan kredit tersebut untuk kebutuhan hidup sehari-hari, sehingga ketika uang tersebut habis usahapun tidak akan jalan/bangkrut.

Literasi keempat adalah penambahan modal melaui bursa efek Indonesia, pelaku UMKM diharapkan dapat memahami bahwa modal itu tidak hanya dari modal sendiri dan bank, namun dapat juga berasal dari penjualan saham. Pelaku usaha memahami keuntungan dan kerugian masuk dalam bursa efek Indonesia, memahami tahapan untuk menjadi perusahaan go publik.

Apabila UMKM di setiap desa berkembang maka dengan dana desa, setiap desa dapat membuat swalayan/toko sendiri untuk menjual barang-barang UMKM di desa masing-masing, dapat juga menjualkan hasil produk dan jasa dari desa lain, bahkan UMKM juga bisa dilakukan eksport. Dengan kerja sama yang baik antara pemerintah, OJK, UMKM dan desa akan tercipta keselarasan, harapannya UMKM akan menjadi tuan rumah di negri sendiri dan akan mencapai kemandirian ekonomi nasional.

\section{Peluang Replikasi}

UMKM dan desa merupakan pemikiran yang baik dalam rangka mencapai kemandirian ekonomi nasional. Literasi keuangan UMKM di tingkat desa yang diselenggaran oleh desa bekerja sama dengan OJK dapat diterapkan di seluruh desa di wilayah Indonesia. Selain edukasi literasi keuangan, pendampingan, serta target untuk memajukan UMKM di desa harus ada. Sehingga ada UMKM yang bisa berkembang sebagai percontohan bagi UMKM-UMKM lain yang merupakan golongan UMKM yang tidak mau berkembang.

a. Pendekatan Kebijakan

Prioritas kegiatan dalam rangka memajukan UMKM dari tingkat desa dengan memanfaatkan dana desa dapat dilakukan penetapan kebijakan yang tidak memberatkan pelaku usaha seperti penetapan kebijakan perencanaan keuangan, pembuatan laporan keuangan (ETAB), kebijakan kemudahan unsur kerdit, kebijakan kemudahan pengurusan perizinan usaha, kebijakan UMKM menjadi anggota bursa efek, kenijakan keringanan Pajak.

b. Pendekatan Regulasi

Regulasi merupakan aturan untuk mengatur perilaku manusia, dalam hal ini regulasi yang akan dibuat adalah regulasi-regulasi yang menyangkut dengan upaya desa untuk memajukan UMKM dan menjadikan UMKM sebagai dasar bagi pencapaian kemandirian nasional.

c. Pendekatan Edukasi dan Sosialisasi

Edukasi dalam hal ini menyangkut literasi keuangan UMKM yang meliputi edukasi dibidang perencanaan keuangan, pembuatan laporan keuangan, manfaat dan proses pengajuan kredit, serta ases UMKM yang dapat menembus bursa efek Indonesia. Literasi yang akan diselenggarakan di setiap desa ini akan disosialisasi melalui desa masingmasing, literasi keuangan UMKM desa akan juga disosialisasikan lewat media masa dengan dukungan penuh oleh pemerintahan pusat, OJK juga turut mensosialisasikannya melalui sloganslogannya.

d. Pendekatan Infrastruktur

Infrastruktur yang dibutuhkan untuk melakukan literasi keuangan UMKM berbasis desa ini adalah infrastruktur untuk melakukan pendataan desa tentang informasi UMKM yang ada di wilayah desa tersebut lengkap dengan jenis usaha, serta golongan UMKM. Kemudian infrastruktur berikutnya adalah untuk melakukan pelaksanaan literasi adalah berupa tempat balai desa 
lengkap beserta peralatannya, bahan edukasi seperti lembar kerja, modul, alat tulis, serta konsumsi untuk penyelenggaraan edukasi. Kemudian infrastruktur untuk pendampingan UMKM, pengawasan UMKM sampai menjadi UMKM percontohan. Dalam hal ini desa yang sedang mendapatkan dana desa dapat menganggarkan pengeluarannya untuk kemajuan UMKM. Tentu saja penyelenggaraan ini semua tidak lepas dari peran serta OJK, untuk trainer juga dapat disediakan oleh OJK, dukungan pemerintah juga sangat besar untuk penyelenggaraan ini.

e. Pendekatan Komunikasi

Pendekatan komunikasi sangat dibutuhkan dalam edukasi literasi keuangan berbasis desa ini, tentu saja komunikasi yang baik antara pihak pemerintah, OJK, desa, serta UMKM. Karena didesain melibatkan dana desa maka pemerintah dapat menghimbau kepada desa-desa untuk memprioritaskan untuk kemajuan UMKM. OJK sebagai penggagas literasi berbasis desa ini dapat berkomunikasi dengan pemerintah, desa, dan pemilik UMKM, apa saja yang akan dibutuhkan. Desa sendiri dalam menggelontorkan dana juga harus mempunyai syarat-syarat dan kebijakankebijakan sendiri untuk dana desa yang akan dipergunakan untuk kemajuan UMKM.

\section{Daftar Pustaka}

[1] Dwitya Aribawa, 2016. Pengaruh Literasi Keuangan Terhadap Kinerja Dan Keberlangsungan UMKM di Jawa Tengah. Jurnal Siasat Bisnis Vol 20 No. 1, Januari 2016 Hal: 1 - 13

[2] G.T Sutoso dan Widyaiswara, 2015 Masyarakat Ekonomi Asean (MEA) Dan Perekonomian Indonesia diases

[3] Undang-Undang desa 6 tahun 2014

http://www.bppk.kemenkeu.go.id/publikasi/ artikel/150-artikel-keuangan-umum 